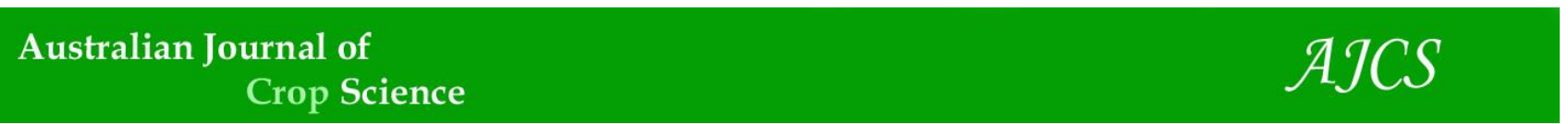

AJCS 14(09):1465-1472 (2020)

ISSN:1835-2707

doi: 10.21475/ajcs.20.14.09.p2551

\title{
Spatial variability in soybean associated with soil fertility variations in a no-tillage system
}

\author{
Michel Esper Neto ${ }^{1}$, Evandro Antonio Minato ${ }^{1}$, Anderson Takashi Hara ${ }^{1}$, Silas Maciel de Oliveira ${ }^{1}$, Edner \\ Betioli Junior ${ }^{1}$, Antonio Carlos Andrade Gonçalves ${ }^{1}$, Tadeu Takeyoshi Inoue ${ }^{1}$, Marcelo Augusto Batista ${ }^{1}$ \\ Maringá State University, UEM - PR - Av. Colombo, 5790, Zona 7, CEP 87020-900 Maringá - PR, Brasil
}

*Corresponding author: michelesper14@gmail.com; pg53383@uem.br

\begin{abstract}
Understanding the spatial variability of soil fertility is necessary for preventing nutrient losses or excessive agricultural inputs. The aim of this research was to evaluate the spatial variability of the chemical characteristics of a Typic Hapludox cultivated with soybean for 110 days at different depths and the impacts of these characteristics on crop yield. Soil samples were collected at a total of 80 points in an area of $5000 \mathrm{~m}^{2}$. The contents of $\mathrm{P}, \mathrm{Ca}, \mathrm{Mg}, \mathrm{S}, \mathrm{Cu}, \mathrm{Fe}, \mathrm{Zn}$ and $\mathrm{Mn}$ were analyzed, in addition to $\mathrm{pH}$ and $\mathrm{H}+\mathrm{Al}$. The data were evaluated through descriptive statistics and geostatistical tools, and kriging maps were made based on semivariogram adjustments. Most of the soil fertility variables showed moderate or strong spatial dependence. The statistical moments obtained for the distributions showed that the symmetry of the distributions allowed the use of geostatistics techniques. In general, the greater the soil depth was, the lower the nutrient levels were. The soybean yield range ( $29.5 \mathrm{~m}$ ) was similar to the $P$ range in the $0.0-0.20 \mathrm{~m}$ soil layer $(29.2 \mathrm{~m})$. P influenced the soybean yield the most, as expressed by the similarity between the two kriging maps. In regions with more phosphorus at deeper soil layers, higher soybean yields were obtained.
\end{abstract}

Keywords: geostatistics, semivariogram, maps, soil fertility, phosphorus Abbreviations: $\mathrm{DQ}$ interquartile range; $\mathrm{Ca}^{2+}{ }_{-}$calcium; $\mathrm{Mg}^{2+}{ }_{-}$magnesium; $\mathrm{P} \_$phosphorus; $\mathrm{Cu}^{2+}{ }_{-}$copper; $\mathrm{Fe}^{2+}{ }_{-}$iron; $\mathrm{Zn}^{2+}{ }_{-} \mathrm{zinc} \mathrm{Mn}^{2+}$ manganese; $\mathrm{S}_{-} \mathrm{SO}_{4}{ }^{-\overline{2}}$ _sulfur; $\mathrm{pH}$ _active acidity; $\mathrm{H}+\mathrm{Al} \_$potential acidity; $\mathrm{C}_{0}$ _nugget; $\mathrm{C}_{0}+\mathrm{C}_{1}$ sill; $\mathrm{a}_{-}$range; $\mathrm{SDI}$ spatial dependency index; SSR_sum of squared residuals; $\mathrm{R}^{2}$ determination coefficient; $\mathrm{CV}_{-}$coefficient of variation.

\section{Introduction}

Societal pressures on production systems to optimize resources and reduce production costs have been a constant in recent years. In agriculture, conservation practices are being carried out for the purposes of preserving the environment, increasing sustainability and improving soil quality (Lima et al., 2013). In this context, the no-tillage system is the main conservationist practice adopted by farmers to minimize the negative impacts of conventional farming systems (Topakci et al., 2011).

In no-tillage systems, there is no soil plowing; therefore, almost all applications of agricultural inputs are performed superficially, without incorporation. Moreover, the deposition of various materials from the previous crops causes vertical variability in nutrient availability (Zanão Júnior et., 2010). The horizontal variation in nutrients is also related to the irregular distribution of these materials. Even homogeneously managed sites show heterogeneity in their soil chemical properties (Montezano et al., 2008). Other factors responsible for the two-way spatial variability (vertical and horizontal) are related to weathering, such as the origin material, relief, climate, time and microorganisms, which do not occur uniformly (Cavalcante et al., 2007).

Most fertilizer and lime recommendations are made considering large areas to be homogeneous, as if these areas do not present spatial variability. Such management practices lead to the irrational use of these inputs in terms of both excess and insufficient application; improper inputs reduce crop development and yield, increase production costs and increase the risk of environmental contamination (Zanão Júnior, et al., 2010)

By analyzing the spatial variability of soil fertility, it is possible to achieve sustainable agricultural production through the rational use of fertilizers. In this context, geostatistics emerge as an tool for inferring the spatial continuity of variables through semivariograms that determine the degree of dependence in space (Reichardt et al., 1986). Many researchers have shown that chemical characteristics may have spatial continuity (Schlindwein e Anghinoni, 2000; Cavalcante et al., 2007; Zanão Júnior et al.; Pereira, 2010; Lima et al., 2013; Cherubin et al., 2014).

After verifying the spatial dependence of a regionalized variable through its semivariogram, it is possible to interpolate the variable to non-sampled locations, to represent the variable by means of isoline maps inside a domain, and to generate soil fertility maps that can be the basis for fertilization planning (Zanão Júnior et al., 2010).

The hypothesis of this research is based on the existence of horizontal and vertical variability in the chemical characteristics of soils cultivated in no-tillage systems; these variations directly affect soybean development and yield. Therefore, the specific aim was to evaluate the spatial dependence of soybean yield and the importance of the 
different soil chemical attributes at different depths in a Typic Hapludox cultivated in a no-tillage system for more than twenty years.

\section{Results and discussion}

\section{Descriptive data analysis}

The $\mathrm{P}$ in layer 3 presented the most discrepant data, with eleven outliers. On the other hand, $\mathrm{Mg}^{2+}$ and $\mathrm{Cu}^{2+}$ in layers 2 and 3 presented only one outlier each. The exclusion of discrepant values allows more reliable characterization, mainly as it pertains to position measurements (Libardi et a., 1996).

Table 1 shows the descriptive data analysis, including the results of the normality tests. Normality was confirmed for all variables at all depths. In addition, the values of the position measurements were also similar, indicating that the values deviated slightly from a central value rather than showing an asymmetric distribution.

According to the classifications for the available soil elements proposed by EMBRAPA, (2013), for the soybean crop in Paraná state, the levels of nutrients were classified as high for $\mathrm{Ca}^{2+}(1), \mathrm{Mg}^{2+}\left(1,2\right.$ and 3), $\mathrm{P}(1), \mathrm{Cu}^{2+}(1,2$ and 3), $\mathrm{Zn}^{2+}(1)$ and $\mathrm{Mn}^{2+}(1,2$ and 3$)$, moderate for $\mathrm{Ca}^{2+}(2$ and 3$)$, $\mathrm{Zn}^{2+}(2$ and 3$)$ and $\mathrm{pH}$, and low for $\mathrm{S}^{2} \mathrm{SO}_{4}{ }^{2-}(1,2$ and 3$)$ and $\mathrm{P}$ ( 2 and 3 ). Regarding soybean yield, the mean value obtained (3582 $\mathrm{kg} \mathrm{ha}^{-1}$ ) was numerically higher than the average produced by Paraná State ( $\left.3141 \mathrm{~kg} \mathrm{ha}^{-1}\right)$.

The coefficient of variation (CV) was classified as low (CV $<10 \%)$, moderate $(10 \%<\mathrm{CV}<20 \%)$, high $(20 \%<\mathrm{CV}<30 \%)$ or very high (CV> 30\%). $\mathrm{P}$ (1 and 2$), \mathrm{Zn} \mathrm{(2} \mathrm{and} 3$ ) and $\mathrm{S}^{-\mathrm{SO}_{4}}{ }^{2-}$ (3) showed very high $\mathrm{CVs}$, and $\mathrm{pH}(1,2$ and 3$)$ and yield showed low CVs. The CVs increased with depth. In the process of soil formation, several factors cause vertical variability, including material of origin, relief, climate, weathering and microorganisms (Cavalcante et al., 2007). In addition, anthropological factors related to field management are associated with this kind of variation.

$\mathrm{Ca}^{2+}, \mathrm{Mg}^{2+}, \mathrm{P}, \mathrm{Zn}^{2+}$ and $\mathrm{Mn}^{2+}$ were more concentrated in the surface layer. Some authors have observed a similar phenomenon (Cavalcante et al., 2007; Souza et al., 2010). These nutrients are applied superficially without incorporation into no-tillage systems, which explains this distribution (Dalchiavon et al., 2012). Therefore, due to the low reactivity of limestone, its efficiency is presumed to be reduced in deeper layers, and the $\mathrm{Ca}^{2+}$ and $\mathrm{Mg}^{2+}$ contents are lower in deeper layers (Costa et al., 2007). P is concentrated on the surface due to frequent applications of phosphate fertilizers (Bottega et al., 2013), combined with the low mobility of this element in soil.

Esper Neto et al. (2016) showed the low mobility of $\mathrm{Mn}^{2+}$ in soil similar to that in this study. In addition, successive sprays of foliar $\mathrm{Mn}$ on soybean and corn are carried out annually, contributing to the higher surface contents of $\mathrm{Mn}^{2+} . \mathrm{Zn}^{2+}$ has relatively high mobility in soil (Smanhotto et al., 2010); however, soils with high clay content, iron oxides, or humic and fulvic acids increase the retention of this nutrient. In addition, higher $\mathrm{pH}$ values also decrease the vertical mobility of $\mathrm{Zn}^{2+}$ due to its lower solubility; the same phenomenon can be observed in $\mathrm{Mn}^{2+}, \mathrm{Cu}^{2+}$ and $\mathrm{Fe}^{2+}$.

The $\mathrm{pH}$ values decreased slightly with depth, even though they remained within the range considered appropriate for crop growth. The levels of $\mathrm{H}+\mathrm{Al}$ decreased moderately with depth. The levels of $\mathrm{S}^{-\mathrm{SO}_{4}}{ }^{2-}$ increased with depth. The highest amount of sulfur (S) is found in organic matter, and $\mathrm{S}$ may become labile in its sulfate form $\left(\mathrm{SO}_{4}{ }^{2-}\right)$ after mineralization. In this state, $\mathrm{SO}_{4}{ }^{2-}$ is mobile in the soil, and between 20 and $60 \mathrm{~kg} \mathrm{ha}^{-1}$ year $^{-1}$ can be lost, although this movement is slower in soils with a clayey texture and high iron oxide levels (Rheinheimer et al., 2005). This may have occurred in this study, since this soil presented iron oxide contents between 18 and 36\% (EMBRAPA, 2013). Table 1 shows the values of asymmetry and kurtosis. The coefficients are close to zero, allowing geostatistical techniques to be applied (Dalchiavon et al., 2012).

\section{Geostatistical analysis}

Table 2 shows the adjusted semivariogram models with their coefficients. All variables presented a spatially dependent structure except $\mathrm{pH}(1), \mathrm{Mn}^{2+}(1,2$ and 3$), \mathrm{Zn}^{2+}$ and $\mathrm{Fe}^{2+}(2$ and 3$)$. The theoretical spherical model was a better fit for the semivariance of most soil attributes, followed by the exponential model, which only fit $\mathrm{Fe}^{2+}(1)$ and $\mathrm{SO}_{4}{ }^{2-}(3)$. Both theoretical models are commonly used for soil and plant variables (Cavalcante et al., 2007; Zanão Júnior et al., 2010).

These dependencies mean that the distributions of these variables do not occur at random and are dependent on a range, and the distribution of sample points within the domain was adequate to describe them. On the other hand, when the variables are spatially independent, it is referred to as a pure nugget effect; that is, the semivariogram remains constant and equal to the sill $\left(C_{0}=C_{0}+C\right)$ for any values of $h$. In this case, spatial dependence, if it exists, will be manifested on another scale. The $\mathrm{pH}$ exemplifies this situation. For depth 1 , the spatial independence of $\mathrm{pH}$ was verified, but at the other depths, it was not. In the no-tillage system, liming is performed superficially, and spatial dependence was not detected in the sampling grid of this work, thought it could be detected at smaller distances (Bottega et al., 2013)

Zanão Júnior et al. (2010) cite the importance of the range coefficient $(\mathrm{m})$ of adjusted models, which determines how far a regionalized variable correlates spatially and the distance above which the variable becomes independent in space (Lemos Filho et al., 2008). The range is also important for stipulating the number of "neighbors" for performing data interpolation.

In the present study, the ranges varied from $97.3 \mathrm{~m}$ to $\mathrm{P}$ (3) and $13.8 \mathrm{~m}$ for $\mathrm{pH}$ (3); in addition, these variables presented different range values at different depths, showing the vertical variability of these attributes (Dalchiavon et al., 2012). Furthermore, the range of $P$ in the uppermost layer $(29.2 \mathrm{~m})$ was the most similar to the range of the spatial continuity of soybean yield $(29.5 \mathrm{~m})$.

Analyzing the spatial dependence index $\left[\left(C_{0} / C_{0}+C_{1}\right) \times 100\right]$ showed that 33, 67 and $0 \%$ of the regionalized variables presented strong, moderate and weak dependence, respectively, indicating that the adjusted semivariograms describe much of the attribute variation. As the depth increased, the spatial dependence index values also increased. The distinct chemical reactions along the soil layers can be related to the differences in the patterns of spatial dependence (Dalchiavon et al., 2012). The spatial dependence index found for soybean yield was close to those found by other authors (Milani et al., 2006; Amado et al., 2007)

Considering the coefficients of the adjusted models for the semivariograms, data interpolation was carried out by the kriging method with the purpose of generating spatial 
Table 1: Descriptive analysis of the soil chemical characteristics in the no-tillage system at different depths.

\begin{tabular}{|c|c|c|c|c|c|c|c|c|c|}
\hline \multirow{2}{*}{ Variable } & \multirow{2}{*}{ Mean } & \multirow{2}{*}{ Median } & \multicolumn{2}{|c|}{ Value } & \multirow{2}{*}{$s^{1}$} & \multicolumn{3}{|c|}{ Coefficient } & \multirow{2}{*}{$w^{2}$} \\
\hline & & & Maximum & Minimum & & Variation & asymmetry & kurtosis & \\
\hline Yield $^{3}$ & 3582 & 3589 & 4125 & 2982 & 235 & 6.6 & -0.25 & -0.39 & $\mathrm{~N}$ \\
\hline \multicolumn{10}{|c|}{ Depth 0.0-0.2 m (1) } \\
\hline $\mathrm{pH}$ & 5.0 & 5.0 & 5.3 & 4.7 & 0.1 & 2.4 & 0.24 & 0.34 & $\mathrm{~N}$ \\
\hline $\mathrm{Ca}^{2+}$ & 4.5 & 4.4 & 5.9 & 3.6 & 0.6 & 13.1 & 0.64 & -0.46 & $\mathrm{~N}$ \\
\hline $\mathrm{Mg}^{2+}$ & 1.6 & 1.6 & 2.0 & 1.2 & 0.2 & 11.1 & 0.31 & -0.12 & $\mathrm{~N}$ \\
\hline $\mathrm{H}+\mathrm{Al}$ & 4.4 & 4.4 & 5.1 & 3.5 & 0.3 & 6.4 & -0.43 & 1.73 & $\mathrm{~N}$ \\
\hline$P$ & 18.9 & 18.0 & 33.7 & 9.6 & 5.8 & 30.7 & 0.60 & -0.20 & $\mathrm{~N}$ \\
\hline $\mathrm{SO}_{4}{ }^{2-}$ & 2.7 & 2.6 & 4.1 & 1.8 & 0.5 & 19.0 & 0.62 & -0.10 & $\mathrm{~N}$ \\
\hline $\mathrm{Cu}^{2+}$ & 13.7 & 13.5 & 17.4 & 8.9 & 1.6 & 11.7 & 0.14 & 0.34 & 1 \\
\hline $\mathrm{Fe}^{2+}$ & 58.0 & 57.5 & 73.9 & 48.0 & 5.4 & 9.3 & 0.49 & 0.10 & 1 \\
\hline $\mathrm{Zn}^{2+}$ & 7.0 & 6.9 & 9.6 & 3.9 & 1.1 & 15.9 & -0.06 & 0.17 & 1 \\
\hline $\mathrm{Mn}^{2+}$ & 252.8 & 253.9 & 312.1 & 182.1 & 25.5 & 10.1 & -0.15 & 0.22 & 1 \\
\hline \multicolumn{10}{|c|}{ Depth 0.2-0.4 m (2) } \\
\hline $\mathrm{pH}$ & 5.5 & 5.5 & 5.9 & 5.0 & 0.2 & 3.2 & -0.51 & 0.18 & 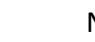 \\
\hline $\mathrm{Ca}^{2+}$ & 3.6 & 3.5 & 4.9 & 2.7 & 0.5 & 15.0 & 0.54 & -0.60 & 1 \\
\hline $\mathrm{Mg}^{2+}$ & 1.4 & 1.4 & 1.9 & 1.0 & 0.2 & 12.2 & 0.31 & 0.05 & 1 \\
\hline $\mathrm{H}+\mathrm{Al}$ & 3.2 & 3.2 & 3.8 & 2.7 & 0.2 & 6.6 & 0.09 & 0.56 & 1 \\
\hline$P$ & 1.8 & 1.6 & 3.4 & 0.5 & 0.7 & 37.2 & 0.69 & -0.2 & 1 \\
\hline $\mathrm{S} \mathrm{SO}_{4}^{2-}$ & 5.7 & 5.4 & 10.3 & 2.4 & 1.6 & 28.1 & 0.64 & 0.4 & 1 \\
\hline $\mathrm{Cu}^{2+}$ & 14.6 & 14.1 & 21.8 & 10.8 & 2.4 & 16.4 & 0.82 & 0.49 & 1 \\
\hline $\mathrm{Fe}^{2+}$ & 88.4 & 88.6 & 105.4 & 64.0 & 9.3 & 10.5 & -0.32 & 0.20 & 1 \\
\hline $\mathrm{Zn}^{2+}$ & 1.4 & 1.3 & 2.8 & 0.2 & 0.6 & 38.0 & 0.06 & -0.05 & 1 \\
\hline $\mathrm{Mn}^{2+}$ & 105.8 & 101.2 & 155.6 & 63.0 & 20.8 & 16.6 & 0.64 & 0.12 & 1 \\
\hline \multicolumn{10}{|c|}{ Depth 0.4-0.6 m (3) } \\
\hline $\mathrm{pH}$ & 5.5 & 5.6 & 6,6 & 4,5 & 0,4 & 6.5 & -0.14 & 1.14 & \\
\hline $\mathrm{Ca}^{2+}$ & 3.3 & 3.1 & 4.9 & 2.2 & 0.7 & 20.2 & 0.50 & -0.67 & 1 \\
\hline $\mathrm{Mg}^{2+}$ & 1.4 & 1.4 & 1.8 & 0.9 & 0.2 & 12.9 & 0.12 & -0.37 & 1 \\
\hline $\mathrm{H}+\mathrm{Al}$ & 3.3 & 3.2 & 4.4 & 2.6 & 0.3 & 10.5 & 0.79 & 0.97 & 1 \\
\hline$P$ & 1.2 & 1.1 & 1.9 & 0.5 & 0.3 & 25.2 & 0.22 & -0.62 & 1 \\
\hline $\mathrm{S}-\mathrm{SO}_{4}{ }^{2-}$ & 7.6 & 6.9 & 14.3 & 3.2 & 2.8 & 36.2 & 0.85 & -0.02 & 1 \\
\hline $\mathrm{Cu}^{2+}$ & 13.4 & 13.0 & 18.7 & 9.5 & 2.2 & 16.1 & 0.60 & -0.11 & 1 \\
\hline $\mathrm{Fe}^{2+}$ & 85.1 & 84.2 & 111.1 & 52.5 & 11.4 & 13.4 & 0.03 & 0.27 & 1 \\
\hline $\mathrm{Zn}^{2+}$ & 1.3 & 1.3 & 2.2 & 0.3 & 0.5 & 36.4 & -0.07 & -0.70 & 1 \\
\hline $\mathrm{Mn}^{2+}$ & 74.7 & 73.0 & 105.2 & 47.1 & 12.5 & 16.7 & 0.20 & -0.32 & $\Lambda$ \\
\hline
\end{tabular}

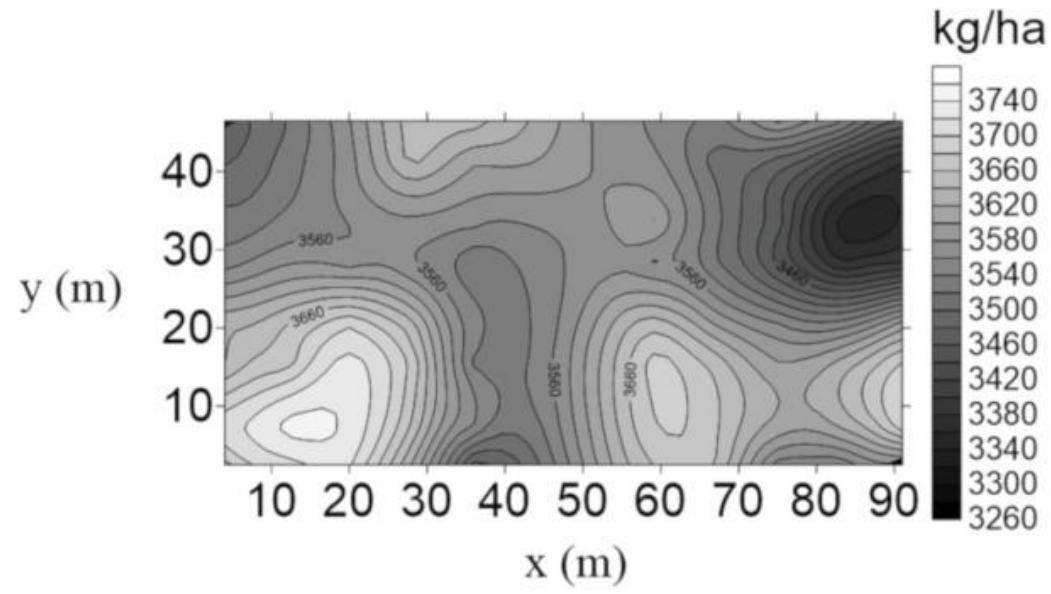

Fig 1. Soybean yield kriging map $\left(\mathrm{kg} \mathrm{ha}^{-1}\right)$. Soybean yield has high variability and is related to the variability of phosphorus content in the topsoil. 
Table 2. Semivariogram coefficients of the chemical characteristics of a Red Eutroferric Latosol in a no-tillage system at different depths.

\begin{tabular}{|c|c|c|c|c|c|c|c|}
\hline Variable & Model & $a^{1}(m)$ & $\mathrm{C}_{0}+\mathrm{C}^{2}$ & $\mathrm{C}_{0}^{3}$ & $\mathrm{SDI}^{4}$ & $\mathrm{SSR}^{5}$ & $\mathrm{R}^{2(6)}$ \\
\hline Yield $^{1}$ & Esferic & 29.5 & 29380 & 58770 & 50 & 0.0000007 & 0.86 \\
\hline \multicolumn{8}{|c|}{ Depth 0.0-0.2 m (1) } \\
\hline $\mathrm{Ca}^{2+}$ & Esferic & 41.0 & 0.002 & 0.019 & 13 & 0.000003 & 0.98 \\
\hline $\mathrm{Mg}$ & Esferic & 87.3 & 0.045 & 0.014 & 31 & 0.00006 & 0.93 \\
\hline $\mathrm{H}+\mathrm{Al}$ & Esferic & 16.2 & 0.017 & 0.084 & 20 & 0.0001 & 0.92 \\
\hline$P$ & Esferic & 29.2 & 35.08 & 13.52 & 39 & 11.2 & 0.94 \\
\hline $\mathrm{S} \mathrm{SO}_{4}{ }^{2-}$ & Esferic & 40.1 & 0.082 & 0.307 & 27 & 0.0014 & 0.96 \\
\hline $\mathrm{Cu}^{2+}$ & Esferic & 58.6 & 2.957 & 1.179 & 40 & 0.142 & 0.93 \\
\hline $\mathrm{Fe}^{2+}$ & Exponential & 21.5 & 30.03 & 6.64 & 22 & 43 & 0.58 \\
\hline $\mathrm{Zn}^{2+}$ & Esferic & 82.1 & 1.56 & 0.713 & 54 & 0.0655 & 0.90 \\
\hline \multicolumn{8}{|c|}{ Depth 0.2-0.4 m (2) } \\
\hline $\mathrm{pH}$ & Esferic & 15.7 & 0.00016 & 0.00002 & 12 & 0.0000002 & 0.82 \\
\hline $\mathrm{Ca}^{2+}$ & Esferic & 27.8 & 0.02967 & 0.01497 & 50 & 0.000031 & 0.70 \\
\hline $\mathrm{Mg}$ & Esferic & 43.9 & 0.01688 & 0.00839 & 50 & 0.000006 & 83 \\
\hline$P$ & Esferic & 30.2 & 0.7050 & 0.1390 & 20 & 0.0134 & 0.94 \\
\hline $\mathrm{S} \mathrm{SO}_{4}{ }^{2-}$ & Esferic & 16.11 & 12.65 & 2.79 & 22 & 1.28 & 0.95 \\
\hline \multicolumn{8}{|c|}{ Depth 0.4-0.6 m (3) } \\
\hline $\mathrm{pH}$ & Esferic & 13.8 & 0.1228 & 0.0259 & 21 & 0.0002 & 0.90 \\
\hline $\mathrm{Ca}^{2+}$ & Esferic & 38.9 & 0.0469 & 0.0164 & 35 & 0.0001 & 0.87 \\
\hline $\mathrm{Mg}$ & Esferic & 60.9 & 0.0413 & 0.0202 & 49 & 0.00002 & 0.94 \\
\hline$P$ & Esferic & 97.6 & 0.2098 & 0.0529 & 26 & 0.0003 & 0.98 \\
\hline $\mathrm{S} \mathrm{SO}_{4}{ }^{2-}$ & Exponential & 15.6 & 7.92 & 2.43 & 69 & 1.31 & 0.71 \\
\hline $\mathrm{Cu}^{2+}$ & Esferic & 65.0 & 0.0286 & 0.01425 & 50 & 0.00005 & 0.68 \\
\hline
\end{tabular}

${ }^{1}$ range; ${ }^{2}$ sill; ${ }^{3}$ nugget; ${ }^{4}$ spatial dependence index; ${ }^{5}$ sum of squared residuals; ${ }^{6}$ determination coefficient
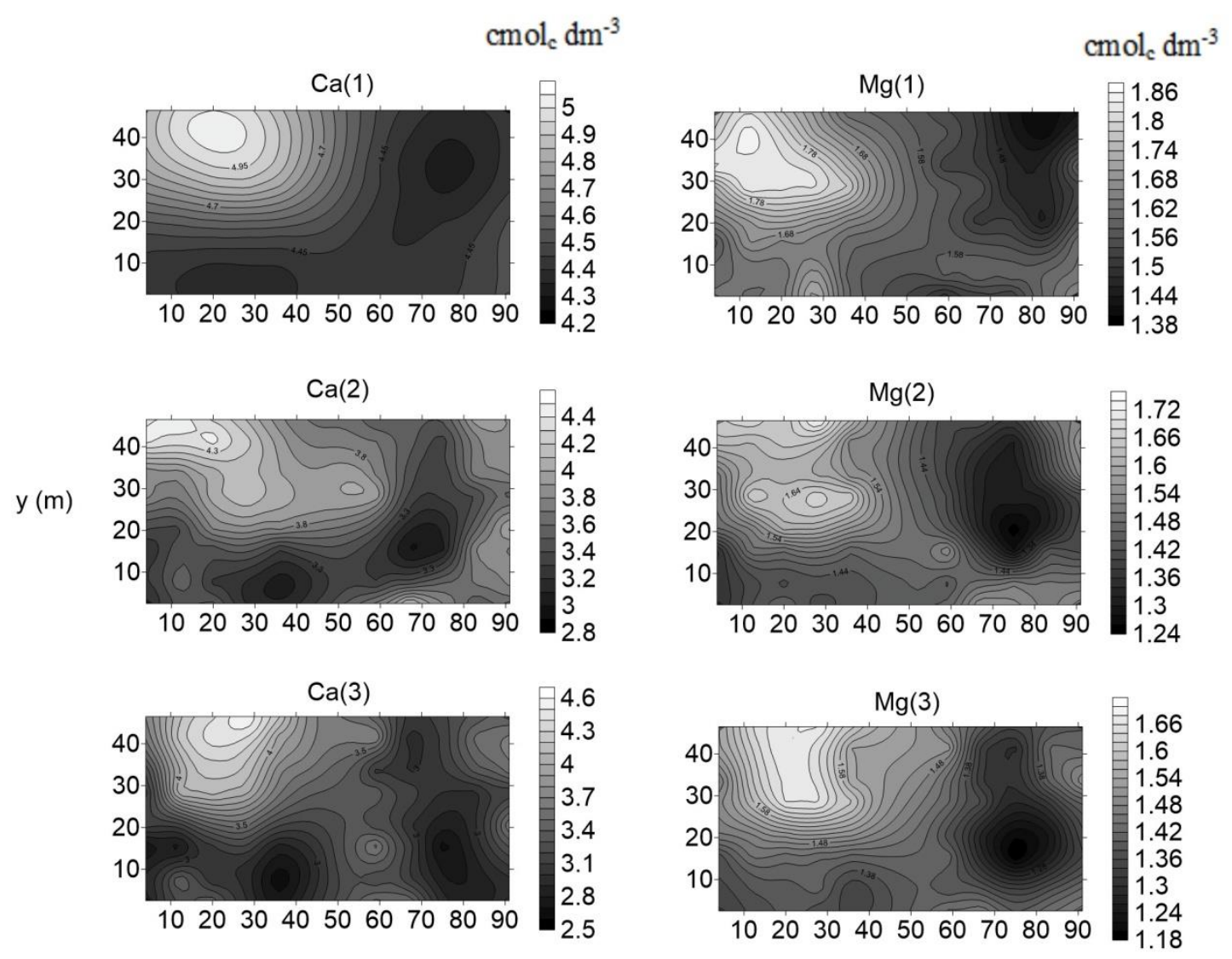

$x(m)$

Fig 2. Ca and $\mathrm{Mg}$ kriging maps $\left(\mathrm{cmol}_{\mathrm{c}} \mathrm{dm}^{-3}\right)$ at different depths. The value surface reveals that the greatest spatial variability was observed in the intermediate layer for $\mathrm{Ca}$ and $\mathrm{Mg}$. 
Table 3. Soil chemical characteristics before sample collection.

\begin{tabular}{|c|c|c|c|c|c|c|c|c|c|c|}
\hline Depth & $\mathrm{pH}^{1}$ & $P^{3}$ & $\mathrm{SO}_{4}^{-2}$ & $\mathrm{Ca}^{2+}$ & $\mathrm{Mg}^{2+}$ & $\mathrm{H}+\mathrm{Al}$ & $\mathrm{Cu}^{2+}$ & $\mathrm{Fe}^{2+}$ & $\mathrm{Zn}^{2+}$ & $\mathrm{Mn}^{2+}$ \\
\hline (m) & $\mathrm{CaCl}_{2}$ & \multicolumn{3}{|c|}{$--m g d^{-3}--$} & \multicolumn{2}{|c|}{ 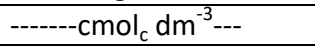 } & \multicolumn{4}{|c|}{-------------mg dm ${ }^{-3}--------$} \\
\hline $0.0-0.2$ & 5.0 & 17.9 & 0.34 & 7.2 & 1.6 & 5.98 & 16.9 & 52.3 & 15.6 & 107.5 \\
\hline $0.2-0.4$ & 5.0 & 12.6 & 0.07 & 5.6 & 1.3 & 5.55 & 21.0 & 73.2 & 8.6 & 91.7 \\
\hline $0.4-0.6$ & 5.3 & 4.6 & 0.06 & 5.6 & 1.3 & 4.78 & 25.1 & 85.4 & 2.4 & 71.5 \\
\hline
\end{tabular}

${ }^{1} \mathrm{pH}$ in $\mathrm{CaCl}_{2}\left(0,01 \mathrm{~mol} \mathrm{~L}^{-1}\right),{ }^{2}$ Organic matter, ${ }^{3} \mathrm{P}, \mathrm{Cu}, \mathrm{Fe}, \mathrm{Zn}$ and $\mathrm{Mn}$ extracted by Mehlich-1 solution; ${ }^{4 \mathrm{~V}}=$ base saturation; Ca, $\mathrm{Mg}$ and Al extracted by $\mathrm{KCl} 1,0 \mathrm{~mol} \mathrm{~L}^{-1} ; \mathrm{H}+\mathrm{Al}$ determined by the SMP method.
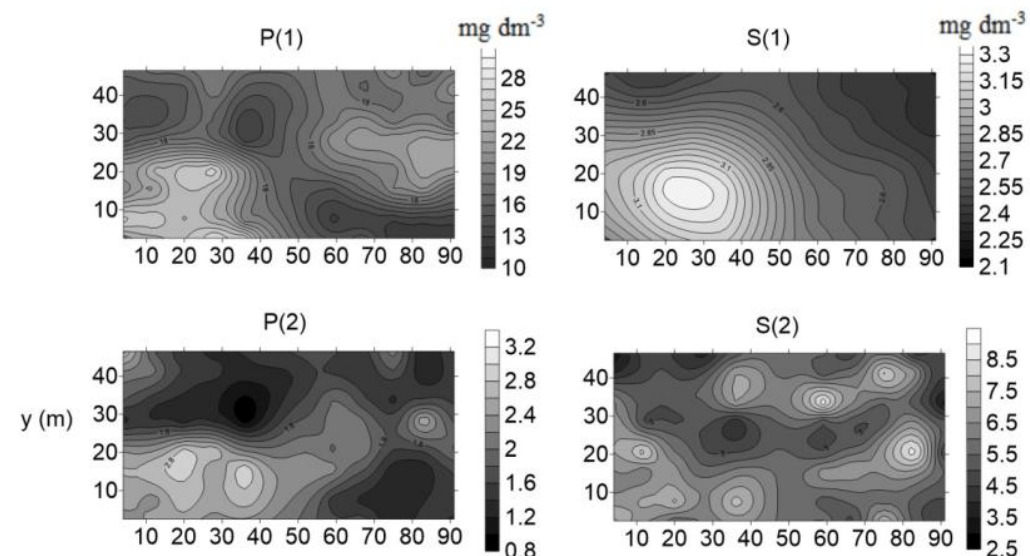

$\mathrm{P}(3)$

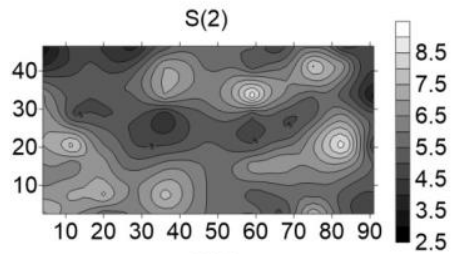

$\mathrm{S}(3)$
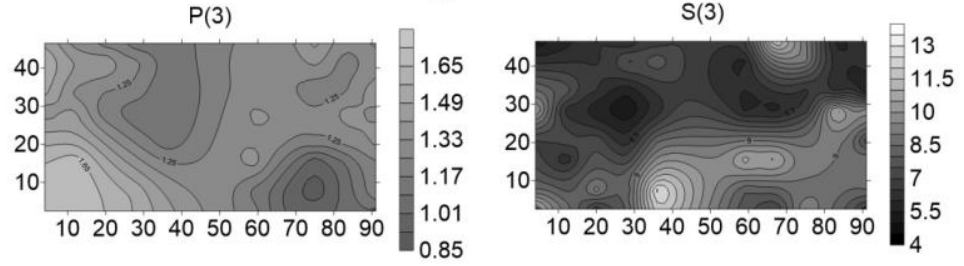

$x(m)$

Fig 3. $P$ and $S$ kriging maps ( $m g d m-3$ ) at different depths. The highest spatial variability in $P$ content was found in the first layer. The highest spatial variability in $\mathrm{S}$ content was found in the third layer.

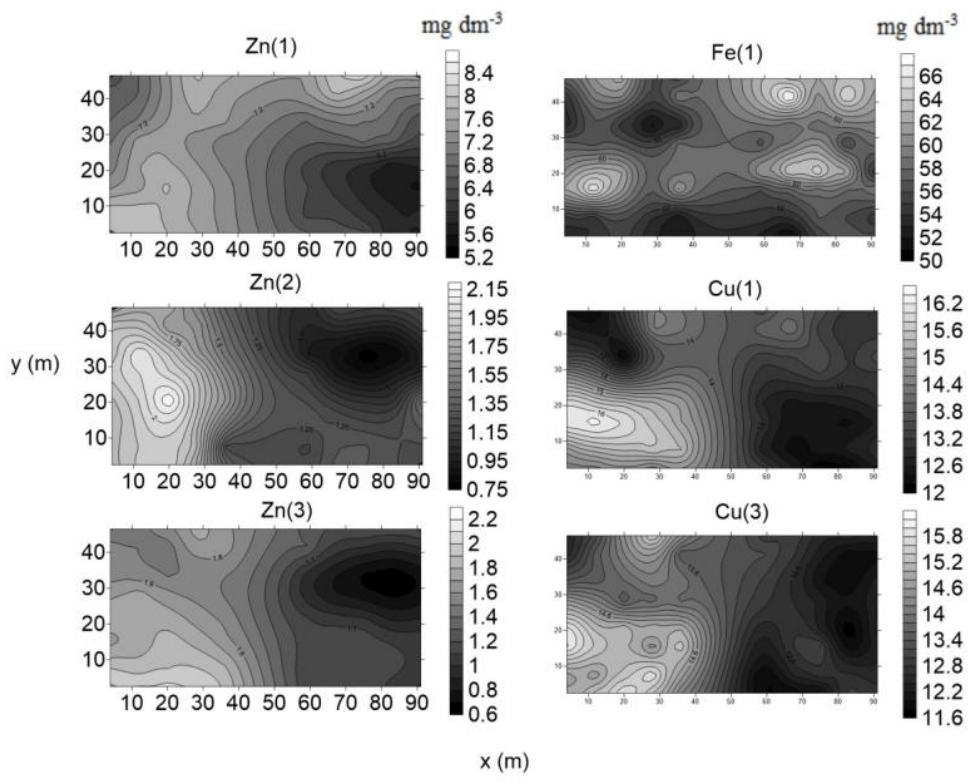

Fig 4. $\mathrm{Cu}, \mathrm{Zn}$ and Fe kriging maps $\left(\mathrm{mg} \mathrm{dm}^{-3}\right)$ at different depths. 


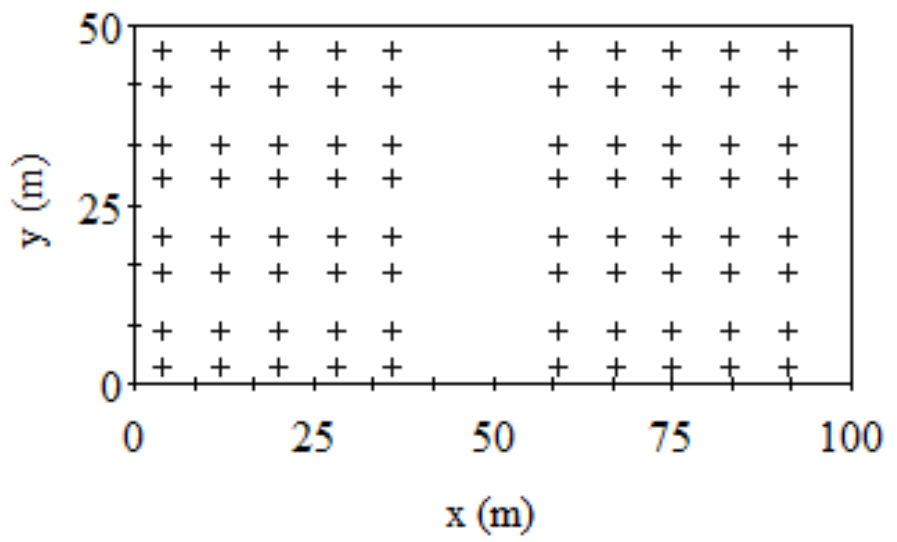

Fig 5. Sketch of the area identifying the sampling points at different depths.

continuity maps. To make the maps, interpretation classes of soil fertility by layer were generated for soybean crops in Paraná state (EMBRAPA, 2013).

Geostatistical software proposes empirically intervals; therefore, it is more reasonable to construct kriging maps according to the interpretation of the nutrients based on fertility classes (Zanão Júnior et al., 2010). The maps were constructed based on these fertility classes (Figures 1, 2, 3, and 4). Maps for the variables that did not present spatial dependence were not constructed.

The $\mathrm{pH}$ values in $\mathrm{CaCl}_{2}$ were classified as adequate (between 5 and 6.4) in almost all the studied areas for layers 2 and 3. The $\mathrm{Ca}$ and $\mathrm{Mg}$ contents were classified as high for soybean crops in the whole sampled area, as they were above 4 and

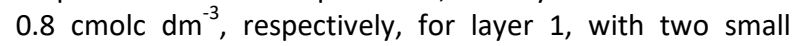
areas classified as moderate $\mathrm{Ca}$ in layer 1 . In layers 2 and 3 , the $\mathrm{Ca}$ contents were classified as moderate, and the $\mathrm{Mg}$ contents remained high (Figure 2).

The $P$ levels were considered high in the whole area in all layers. and In spite of this, in the regions where the $P$ contents were higher, there was higher soybean crop yield, as shown in figures 1 and 3. The kriging maps for the two variables were very similar. In addition, in the spatial dependence modeling, the range of the semivariograms for $P(1)$ and yield were very similar (Table 2 ). In layers 2 and 3 , low levels of $P$ were found in most of the studied area. In addition, average levels of $P$ were found in regions where the highest soybean crop yield was obtained, which is a strong indication of the importance of adequate $P$ in subsurface soil. As the volume of soil fertilized with $P$ increases, the absorption of the element and the development of soybean plants also increase (Nunes et al., 2011). These results suggest the implementation of different phosphate management zones, since the behavior of $P$ in the soil and the yield are not homogeneous (Leão et al., 2007)

The $\mathrm{S}^{-\mathrm{SO}_{4}}{ }^{2-}$ was classified as low for layer 1 in the majority of the study area; nevertheless, in a region where moderate $\mathrm{S}$ $\mathrm{SO}_{4}{ }^{2-}$ content was found in the soil, higher soybean yield was identified (Figure 1). However, the range of the adjusted model in the semivariogram for this variable was not similar to the yield adjustment, as was the case for $\mathrm{P}$ (Table 2). At the other soil depths, the levels of $\mathrm{S}_{-} \mathrm{SO}_{4}{ }^{2-}$ were classified as low, and the maps of $\mathrm{S}_{-} \mathrm{SO}_{4}{ }^{2-}$ content were very homogeneous in these layers.

$\mathrm{Cu}, \mathrm{Zn}$ and $\mathrm{Fe}(1)$ were homogeneous at all depths. The maps showed moderate and high levels of $\mathrm{Cu}$ and $\mathrm{Zn}$, with only small areas classified as low for $\mathrm{Zn}$ in layers 2 and 3. $\mathrm{Cu}$ and $\mathrm{Zn}$ (1) were also present in areas that had higher soybean yields (Figure 4).

\section{Material and methods}

\section{Experimental area}

This study was carried out in the Technology Diffusion Unit of a cooperative society called the Cooperativa Agroindustrial de Maringá in the municipality of Floresta, in the north-central region of Paraná state, Brazil $\left(23^{\circ} 35^{\prime} 42^{\prime \prime}\right.$ $\mathrm{S}$, and $\left.52^{\circ} 04^{\prime} 02^{\prime \prime} \mathrm{W}\right)$. The soil of the experimental area was classified as a Typic Hapludox (Soil Survey Staff, 2014) and had been under no-tillage cultivation for more than 20 years. The climate was classified as Cfa (Alvares et al., 2013). The initial chemical characterization of the sampled area is shown in Table 3.

In September 2015, the area was demarcated by establishing a rectangle of $50 \times 100\left(5000 \mathrm{~m}^{2}\right)$ referenced as a $\mathrm{Y}$ axis $(50 \mathrm{~m})$ and an $\mathrm{X}$ axis $(100 \mathrm{~m})$ in the Cartesian coordinate system. The soybean cultivar NA5909 was sown at a density of 31 seeds $\mathrm{m}^{-2}$ at the beginning of October. All cultural treatments, from soybean planting to harvest, were carried out according to the region and soil chemical analyses (EMBRAPA, 2013).

Soil samples were collected after the soybean harvest at a total of 80 referenced points at the $X$ and $Y$ coordinates (Figure 1) at three depths: 0.0-0.2 (1), 0.2-0.4 (2) and 0.4-0.6 (3) $\mathrm{m}$.

Samples were collected with a cutter shovel (layer 1 ) and a Dutch auger (layers 2 and 3). Each sample was identified and sent to the laboratory to be dried in a forced-air circulation oven at $60^{\circ} \mathrm{C}$ until constant mass. Afterwards, the samples were milled and sieved with a $2 \mathrm{~mm}$ sieve to measure the calcium $\left(\mathrm{Ca}^{2+}\right)$ and magnesium $\left(\mathrm{Mg}^{2+}\right)$ contents extracted by $1 \mathrm{~mol} \mathrm{~L}^{-1} \mathrm{KCl}$. Phosphorus $(\mathrm{P})$, copper $\left(\mathrm{Cu}^{2+}\right)$, iron $\left(\mathrm{Fe}^{2+}\right)$, zinc $\left(\mathrm{Zn}^{2+}\right)$ and manganese $\left(\mathrm{Mn}^{2+}\right)$ were extracted by Mehlich-1 $\left(0.0125 \mathrm{~mol} \mathrm{~L}^{-1} \mathrm{H}_{2} \mathrm{SO}_{4}+0.05 \mathrm{~mol} \mathrm{~L}^{-1} \mathrm{HCl}\right)$. Sulfur $\left(\mathrm{S}^{-\mathrm{SO}_{4}}{ }^{-2}\right)$ was extracted with $0.01 \mathrm{~mol} \mathrm{~L}^{-1}$ calcium phosphate solution, and the active acidity $(\mathrm{pH})$ and potential $(\mathrm{H}+\mathrm{Al})$ were measured (EMBRAPA 2009).

Available $P$ was determined using the molybdate blue method and was measured with a spectrophotometer. $\mathrm{Ca}^{2+}$, $\mathrm{Mg}^{2+}, \mathrm{Fe}^{3+}, \mathrm{Cu}^{2+}, \mathrm{Zn}^{2+}$ and $\mathrm{Mn}^{2+}$ were determined using a Varian AA240FS atomic absorption spectrophotometer. The $\mathrm{S} \mathrm{SO}_{4}{ }^{2-}$ was determined by titration with barium chloride. 
The potential acidity was determined, and $0.01 \mathrm{~mol} \mathrm{~L}^{-1} \mathrm{CaCl}_{2}$ was used to determine the $\mathrm{pH}$ (EMBRAPA 2009).

\section{Exploratory analysis}

The data were initially subjected to exploratory analysis to investigate the presence of possible discrepancies (outliers). To find outlier data, a critical limit was established, defined by the interquartile range (DQ) calculated by subtracting the lower quartile from the upper quartile. Thus, it was possible to establish the upper limits $(\mathrm{Q} 3+1,5 \times \mathrm{DQ})$ and lower limits (Q1 - 1,5 x DQ) of the data, where Q1 refers to the first quartile and Q3 to the third quartile. Then, the data characterization was performed by calculating the mean and median as measures of the central tendency, standard deviation, variance and coefficient of variation as dispersion measures. The Kolmogorov-Smirnov and Shapiro-Wilk tests were performed to verify the normality of the data. Values considered outliers were excluded from the semivariograms and cross-validation but were preserved in the kriging process (Schaffrath et al., 2008).

\section{Geostatistical analysis}

The spatial dependence of the soil chemical attributes was verified through adjustments of the mathematical models used for semivariograms. The obtained data were assumed to show the probability distribution of a random function that attends to the intrinsic stationarity, allowing the estimation of a semivariance function by the Matheron estimator defined by equation 1 .

$\gamma^{*}(\mathrm{H})=\frac{1}{2 \mathrm{~N}(\mathrm{H})} \sum_{\mathrm{i}=1}^{\mathrm{N}(\mathrm{H})} \quad[\mathrm{Z}(\mathrm{s})-\mathrm{Z}(\mathrm{s}+\mathrm{H})]^{2}$

$\gamma^{*}(\mathrm{H})$ is the semivariance as a function of the separation distance between two points, $N(h)$ is the number of pairs of measured values $Z(s)$, and $Z(s+H)$, separated by a sample distance, is the modulus of vector $h$.

The models adjusted to the semivariograms were spherical and exponential and showed the nugget $\left(C_{0}\right)$, sill $\left(C_{0}+C_{1}\right)$ and range (a) as coefficients. Subsequently, the spatial dependency index (SDI) was calculated (Cambardella et al., 1994). This index uses a relationship between the coefficients of the models $[(\mathrm{CO} / \mathrm{CO}+\mathrm{C} 1) \times 100]$ to classify the spatial dependence as weak (SDI > 75\%), moderate $(25 \% \leq$ $\mathrm{SDI} \leq 75 \%)$ or strong (SDI $<25 \%$ ).

After the spatial dependence was verified, inferences of the variables to the non-sampled regions were made using the best non-biased linear estimator (kriging). This method uses the sum of the weights equal to a unit and the minimum variance using 16 nearest neighbors and a search radius of same distance as the range, thus allowing the creation of maps of the spatial distribution of the soil chemical attributes. The maps were generated using the Surfer program, version 8.0.

\section{Conclusion}

Horizontal and vertical variabilities in soil chemical characteristics contribute to variability in soybean crop yield. Most of the variables at the three depths evaluated showed spatial dependence on the scale adopted for the present study.

Among the studied variables, the $P$ in the superficial layer showed a semivariogram range equivalent to that obtained for the soybean yield, and the respective maps obtained by kriging were similar, demonstrating the impact of this variable on the crop. In addition, regions with more phosphorus at deeper soil layers also produced higher yields.

\section{Acknowledgements}

The authors would like to thank CNPq for the financial support and for granting the scholarship for the experiment and research PROC-141140/2017-8 and the Soil Study Group from Universidade Estadual de Maringá (GESSO-UEM). There is no conflict of interest in performing the research or publishing this manuscript.

\section{References}

Alvares CA, Stape JL, Sentelhas PC, Moraes Gonçalves JL \& Sparovek G (2013). Köppen's climate classification map for Brazil. MeteorZeitsch.22:711-728.

Amado TJC, Pontelli CB, Santi AL, Viana JHM \& Sulzbach LADS (2007). Variabilidade espacial e temporal da produtividade de culturas sob sistema plantio direto. PesqAgrop Bras.42:1101-1110.

Bottega EL, Queiroz DM, Carvalho FAP andAlves CMS (2013). Spatial variability of soil attributes in no a no-tillage system with crop rotation in the brazilian savannah. Revde Ciênc Agron.44:1-9.

Cambardella CA, Moorman TB, Parkin TB, Karlen DL, Novak JM, Turco RFand Konopka AE (1994). Field-Scale Variability of Soil Properties in Central lowa Soils. Soil Scien SociAmeri J.58:1501-1511.

Cavalcante E, Silva G, Alves MC, Pereira GT\& Souza ZM (2007). Variabilidade espacial de MO, P, K e CTC do solo sob diferentes usos e manejos. Cien Rural.37:394-400.

Cherubin MR, Santi AL, Eitelwein MT, Ros CO\& Bisognin MB (2014). Sampling grids used to characterise the spatial variability of $\mathrm{pH}, \mathrm{Ca}, \mathrm{Mg}$ and $\mathrm{V} \%$ in Oxisols. $\mathrm{R}$ Cien Agron.45:659-672.

Costa MJ, Rosa Junior EJ, Rosa YBCJ, Souza LCF\& Rosa CBJ (2007). Atributos químicos e físicos de um Latossolo sendo influenciados pelo manejo do solo e efeito da gessagem. Acta Scient Agron. 29:701-708.

Dalchiavon FC, Carvalho MP, Andreotti M\& Montanari R (2012). Variabilidade espacial de atributos da fertilidade de um Latossolo Vermelho Distroférrico sob Sistema Plantio Direto. R Cien Agron. 43:453-461.

EMBRAPA (2009). Manual de análises químicas de solos, plantas e fertilizantes. $2^{\circ}$ ed. Rio de Janeiro.

EMBRAPA (2013). Tecnologias de Produção de Soja -Região Central do Brasil 2014. $1^{\circ}$ ed. Londrina

Esper Neto M, Batista MA, Inoue TT, Bertonha A\& Costa ACS (2016). Soil chemical attributes of a Dystroferric Red Latosol (Oxisol) treated with an alkaline effluent from a pharmaceutical industry. Semina:CiencAgra. 37:30373046.

Guimarães EC (2004). Geoestatística básica e aplicada. $1^{\circ}$ ed. Uberlândia;

Leão AB, Andrade ARS \& Chaves LHG (2007). Spatial variability of phosphorus in soil from irrigated perimeter Engenheiro arcoverde PB. R CiencAgron. 38:1-6.

Lemos Filho LCA, Ednaldo MAF, Bastos LA \& Andrade (2008). Spatial variability of soil density and organic matter content in area cultivated with sugar cane (Saccharum officinarumL).R CiencAgron.23:193-202.

Libardi PL, Manfron PQ, Moraes SO \& Stuon RL (1996) Variabilidade da umidade gravimétrica de um solo hidromórfico.. Rev Bras Cienc Solo.20:1-12. 
Lima JSS, Silva SDA\& Silva JM (2013). Variabilidade espacial de atributos químicos de um Latossolo Vermelho-Amarelo húmico cultivado com café. R Cienc Agron. 44:16-23.

Milani L, Souza EG de, Uribe-Opazo MA, Gabriel Filho A, Johann JA\&Pereira JO. (2006) Unidades de manejo a partir de dados de produtividade. Acta Scient Agron.28: 1-9.

Montezano ZF, Corazza EJ\& Muraoka T (2008). Variabilidade de nutrientes em plantas de milho cultivado em talhão manejado homogeneamente. Bragantia.67:969-976.

Nunes RS, Sousa DMG, Goedert WJ\& Vivaldi LJ (2011). Distribuição de fósforo no solo em razão do sistema de cultivo e manejo da adubação fosfatada. Rev Bras Cienc Solo. 35:877-888.

Reichardt K, Vieira SR\& Libardi PL (1986). Variabilidade espacial de solos e experimentação de campo. Rev Bras Cienc Solo. 10:1-6.

Rheinheimer DDS, Alvarez JWR, Osorio Filho BD, Silva LS \& Bortoluzzi EC (2005). Resposta de culturas à aplicação de enxofre e a teores de sulfato num solo de textura arenosa sob plantio direto. Cienc Rural. 35:562-569.

Schaffrath VR, Tormena CA, Fidalski J\& Gonçalves ACA (2008). Variabilidade e correlação espacial de propriedades físicas de solo sob plantio direto e preparo convencional. Rev Bras Cienc Solo.32:1369-1377.

Schlindwein JA \& Anghinoni I (2000). Variabilidade horizontal de atributos de fertilidade e amostragem do solo no sistema plantio direto. Rev Bras Cienc Solo. 24:85-91.

Smanhotto A, Sousa A de P, Sampaio SC, Nóbrega LHP\& Prior M (2010). Cobre e zinco no material percolado e no solo coman aplicação de água residuaria de suinocultura em solo cultivado com soja. Eng Agric. 30:347-357.

Souza ZM, Cerri DGP, Colet MJ, Rodrigues LHA, Magalhães PSG\& Mandoni RJA (2010) Análise dos atributos do solo e da produtividade da cultura de cana-de-açúcar com o uso da geoestatística e árvore de decisão. Cienc Rural. 40:840847

Topakci M, Karayel D, Canakci M, Furat S\& Uzun B (2011) Sesame hill dropping performance of a vacuum seeder for different tillage practices. Appli Eng inAgric.27:203-210.

Zanão Júnior LA, Lana RMQ, Guimarães EC\& Pereira JMA (2010). Variabilidade espacial dos teores de macronutrietes em latossolos sob sistema de plantio direto. Rev Bras Cienc Solo.34:389-400.

Zanão Júnior LA, Lana RMQ, Carvalho-Zanão MP\& Guimarães EC (2010). Variabilidade espacial de atributos químicos em diferentes profundidades em um Latossolo em sistema de plantio direto. R Ceres.57: 429-438. 